\title{
Was the jury ever self informing?
}

\author{
Daniel Klerman ${ }^{1}$
}

For nearly two centuries, legal historians have believed that the medieval English jury differed fundamentally from the modern jury. Its members hailed from the immediate vicinity of the dispute and came to trial already informed about the facts. Jurors based their verdicts on information they actively gathered in anticipation of trial or which they learned by living in small, tight-knit communities where rumour, gossip, and local courts kept everyone informed about their neighbours' affairs. Interested parties might also approach jurors out of court to relate their side of the case. Witness testimony in court was thus unnecessary. The jurors themselves were considered the witnesses not necessarily eye-witnesses, but witnesses in the sense that they reported facts to the judges. ${ }^{2}$ They were self informing; they 'came to court more to speak than to listen'. ${ }^{3}$

The idea of the self-informing jury has provided a powerful explanation for many legal developments. Thayer and Wigmore used it to explain the late development of rules regulating oral evidence at trial. No such rules were necessary in the Middle Ages, because witness testimony was rare. ${ }^{4}$ For Langbein, the decline of the self-informing jury in the fifteenth and sixteenth centuries explained the increasing role of justices of the peace in the prosecution of crime. In medieval times, there was no need for the government to marshal evidence against suspected criminals, because the jury knew or collected that information on its own. As early modern jurors became more ignorant of the facts, the government turned to justices of the peace to assemble the prosecution case. ${ }^{5}$ More recently, Green explained the medieval jury's extensive discretion and power to nullify the law as a consequence of the selfinforming jury. Because little evidence was presented in court, judges knew almost nothing about the facts of cases and so could not prevent jurors from deciding cases according to their own notions of culpability. ${ }^{6}$

Although there have long been sceptics, ${ }^{7}$ modern doubts about the selfinforming jury begin with the publication in 1988 of Twelve Good Men and 
True. ${ }^{8}$ Three of the authors in this collection questioned the extent to which jurors were self informing. McLane and Post suggested that some fourteenthcentury juries may not have been self informing, while Powell argued more generally that fifteenth-century jurors heard evidence in court. For the most part, all three relied on evidence about jury composition. Some fourteenthcentury jurors and most fifteenth-century jurors did not come from the village or even the hundred ${ }^{9}$ where the crime allegedly occurred, so they were unlikely to have known about the case. The authors also put forward other arguments, including the practice of releasing a suspect if no accuser came forward to present evidence against him. ${ }^{10}$ Such acquittals might suggest that jurors did not know enough to convict without the in-court testimony of the victim. Although McLane and Post confined their conclusions to the fourteenth century, Powell questioned whether the jury had ever been self informing. ${ }^{11}$ 'My suspicion', he wrote, 'is that criminal trial juries were never entirely self informing in the strict sense in which the term has been interpreted, and that even in the earliest days of jury trial, accusers and witnesses had the chance to inform the jury in court'. ${ }^{12}$ Surveying the evidence a few years later, Fisher lamented that "the scant trial records of those early years make it hard to confirm or rebut this theory of the "self-informing" criminal jury . . .'13

The evidence put forward by McLane, Post and Powell is certainly provocative, but it does not prove that later medieval juries were not self informing. Even if only a few jurors were from the relevant hundred, those jurors might have known or gathered relevant information which they shared with other jurors. ${ }^{14}$ And, as Musson put it, 'the self-informing character of trial juries was tempered,' but not negated by the evidence he uncovered that early fourteenth-century jurors sometimes heard witnesses in court. ${ }^{15}$ Nevertheless, it is not my intention here to suggest reinterpretations of the fourteenth- and fifteenth-century evidence. Rather, I hope to address broader issues raised by Powell and Fisher. Was the jury ever self informing? Did the medieval jury hear witness in court? Could a jury be self informing and hear witnesses in court? Recent writers have not seen it necessary to present primary source evidence in favour of the idea that the medieval jury was self informing. ${ }^{16}$ Now that serious scholars have questioned the theory, it is necessary to examine the sources afresh. The need for fresh evidence is especially acute because the modern debate has focused on the criminal jury, while earlier writers were more concerned with civil cases. ${ }^{17}$

This chapter will attempt to show that the thirteenth-century criminal jury was self informing. It argues that jurors came to court with extensive knowledge of the facts. They lived near the place where the crime allegedly occurred and they did not need in-court testimony to know whether a suspect was guilty. Nevertheless, jurors also probably learned from trial. The defendant undoubtedly spoke at trial and may have swayed jurors. In appeals (private prosecutions), the prosecutor, who was usually the victim, also spoke in court, and jurors could have learned from him or her. ${ }^{18}$ Judges questioned 
defendants and prosecutors and spoke with jurors, and such colloquies might also have contributed to the jurors' opinions. Local officials, such as the coroner or sheriff, were present at trial, and their testimony could also have influenced the jury. Finally, although less frequently, others with information about the case might speak up at trial.

The fact that jurors learned from defendants, prosecutors, judges, officials and other witnesses might seem to contradict the idea that the jury was self informing. It could be said to confirm Powell's conjecture that 'criminal trial juries were never entirely self informing. ${ }^{19}$ Nevertheless, whereas Powell emphasised the similarity between medieval and post-medieval jurors, I emphasise the differences. Self informing is a matter of degree, but differences in degree can still be large and important. Modern jurors know practically nothing about the cases they decide, and rely exclusively on in-court testimony. In fact, those with knowledge of the parties or circumstances are routinely excluded from the jury. Early modern jurors learned most of what they needed to know in court. They may have known a little about the facts of the case or the people involved, but such knowledge did not disqualify them from service. Nevertheless, informed jurors were increasingly required to present their evidence under oath in open court. ${ }^{20}$ Medieval jurors knew a lot and were selected for that reason. They only occasionally heard testimony, and what they learned in court was less important. To borrow a phrase from Green, there was testimony 'alongside self informing. ${ }^{21}$ Although they heard witnesses, a wide gulf separates the thirteenth- and the twentieth-century jury.

As noted above, the idea of the self-informing jury is important because it helps explain developments in the history of evidence law, prosecution and jury nullification. For these purposes, it is not necessary that the jury was entirely self informing or that it never heard the testimony in court. Rather, it is enough that jurors were sufficiently well informed that regulation of in-court testimony was not seen as important, that the government did not feel the need to assist in the gathering of prosecution evidence, and that judges knew significantly less about the facts than did the jurors.

Powell implied that the term 'self informing' has usually been interpreted 'strictly' to exclude the idea that jurors learned anything from trial. ${ }^{22}$ While there are statements in the literature to support that interpretation, ${ }^{23}$ some of the principal proponents of the self-informing hypothesis have been more moderate. Even before modifying his views in his 1988 'Retrospective,' Green believed that '[t]he trial often may have constituted an important part of the process by which the jury informed itself or confirmed its earlier impressions. ${ }^{24}$ And even Maitland and Stephen noted examples of in-court testimony. ${ }^{25}$

This chapter focuses on the thirteenth-century criminal jury. It discusses the thirteenth century, because the sources from this period are more plentiful and because if the jury was ever self informing, it was self informing then. It marshals evidence from criminal cases, because the recent debate has focused on such cases and because Seipp has recently written on the self-informing 
nature of the civil jury. ${ }^{26}$ Although this chapter focuses on the trial jury, it will also consider the presenting jury, ${ }^{27}$ because during the thirteenth century the two juries are often difficult to distinguish and because presenting jurors usually served on the trial jury. In fact, because the presenting jury was drawn only from the hundred, while the trial jury included representatives from the four neighbouring villages, the presenting jury had access to less local knowledge than the trial jury.

\section{Jury composition}

McLane, Post and Powell based their arguments against the self-informing jury primarily on evidence of jury composition, so it is appropriate to begin with that issue. Self-informing juries should be from the locality where the crime was allegedly committed. Ideally, they are from the villages closest to the scene of the crime. At the very least, they hail from the relevant hundred. McLane, Post and Powell showed that fourteenth- and fifteenth-century sheriffs were unable to assemble juries composed exclusively of men from the relevant hundred, much less from nearby villages.

In contrast, thirteenth-century criminal juries consisted of twelve freeholders from the hundred and twenty people from the nearest four villages. This is especially clear for the eyre. ${ }^{28}$ All freeholders of the county and four lawful men and the reeve from every village were summoned to the eyre. The hundred bailiff and/or electors chosen by him then chose the presenting jurors from among those present at the eyre. If a case went to trial, four lawful men and the reeve from each of the nearest four villages were sworn and added to presenting juries to constitute the trial jury. ${ }^{29}$

The existence of separate juries for each hundred is well attested to by the structure of the eyre rolls, which divide cases by presenting district. In addition, lists of jurors, which survive for many eyres, invariably show twelve jurors for each hundred..$^{30}$ Often the plea rolls also show that representatives of the nearby villages participated in the trial jury. Although the participation of the villages was not always recorded, the failure to do so probably reflects variation in enrolling practice. ${ }^{31}$ If the villagers were indeed absent, this would have resulted in an amercement, ${ }^{32}$ which would have been recorded. While plea rolls record a number of 'defaults' for failure to attend the eyre as required by the summons, the number of such defaults was small, especially in comparison to the enormous number of people who were summoned. ${ }^{33}$

At this point it is sensible to step back and reflect on the implications of the fact that eyre jurors were not selected until the eyre itself began. Civil jurors and gaol delivery ${ }^{34}$ jurors were summoned in advance for jury service and so could make inquiries and be informed by the parties before they left for court. ${ }^{35}$ The four lawful men and reeve from each village, who were summoned by the sheriff to be eyre trial jurors, would have had a similar opportunity to gather evidence before the eyre, but the twelve presenting jurors, who also formed 
the nucleus of the trial jury, would not. Perhaps some of them could anticipate that they would be chosen to be jurors. Before the eyre even began, the hundred bailiffs might have notified those they would choose as electors, and the electors might have notified those they would choose as the remaining jurors. If so, the jurors could have discussed the cases with those who would have useful information. On the other hand, there is no evidence that jurors had advance notice they would be chosen, so they may have come to the eyre without any particular preparation. While they probably knew something about the offences and offenders from living in the relevant hundred, this may not have been sufficient. Fortunately, there were many opportunities for them to inform themselves at the eyre before trial. They could talk to representatives of the villages, to coroners, to other officials, and to other freeholders who had been summoned. Those with an interest in particular cases might also approach them to tell them their side of the story.

The discussion so far has concerned trials in eyre. Thirteenth-century suspects could also be tried at gaol delivery. Unfortunately, much less is known about gaol delivery than about the eyre. In the preface to his edition of late thirteenth-century Wiltshire gaol deliveries, Pugh concluded that suspects were frequently tried before juries from hundreds which had no apparent relationship to the crime and that the four neighbouring villages played little if any part. ${ }^{36}$ As will be discussed below in section IV, it is not surprising that gaol delivery jurors were less local than eyre juries. Nevertheless, my own survey of early gaol delivery rolls suggests that the neighbouring villages played a role throughout the thirteenth century. ${ }^{37}$

\section{Cases without victim-prosecutor participation}

One of the more convincing arguments that Post and Powell advanced against the self-informing jury theory is that defendants were frequently released without trial if no accuser came forward against them at gaol delivery. ${ }^{38}$ There are alternative explanations for this phenomenon. Perhaps judges released such defendants because they thought that if a victim did not feel sufficiently aggrieved to come to court, the crime was not serious enough to merit trial. Nevertheless, Post and Powell were correct that this practice might imply that the victim-accuser usually presented testimony at trial and that, in the absence of such testimony, the jury lacked sufficient information to convict. It is therefore instructive to consider how similar cases were treated in the thirteenth century.

The most comparable cases were appeals (private prosecutions) in which the appellor (prosecutor) had died, had retracted his or her case, had settled with the defendant, or had decided he or she no longer wanted to prosecute. For most of the early thirteenth century, judges released defendants in such cases without trial. For a brief period around 1220 and more permanently starting in the mid-1240s, judges began routinely to put these defendants to 
Table 3.1 Jury verdicts by level of appellor participation, 1218-22 and 1246-94

Level of appellor participation

Number in data set

$\%$ guilty

Appellor died before trial

18

33

Appellor retracted or did not prosecute

280

44

Appellor settled with defendant

89

78

Appellor prosecuted the case to jury trial

126

71

Notes: ‘\% guilty’ includes cases in which the jury said the defendant was guilty of some, but not all, of the charges brought against him. Nearly all cases in which the 'appellor settled with the defendant' were also cases in which the 'appellor retracted or did not prosecute'. For an example of such a case, see below pp. 67-8. The row labelled 'appellor prosecuted the case to jury trial' includes cases which were quashed for technical reasons, but then sent to jury trial anyway.

trial, despite the appellor's lack of interest. ${ }^{39}$ The mere fact that such cases were put to jury trial suggests that the jury was self informing and not dependent on testimony by the victim-accuser.

Even stronger evidence comes from the verdicts rendered in such cases, which are summarised in Table 3.1. These figures come from a data set of more than a thousand eyre appeals from fourteen counties during the period 1194-1294. ${ }^{40}$ As can be seen from the table, jurors often rendered guilty verdicts even when accuser participation was minimal. Even when the appellor had died, jurors rendered guilty verdicts a third of the time. When the appellor had retracted or did not prosecute at the eyre, the jury still convicted more than forty percent of the time. It is highly unlikely that appellors provided any evidence to the jury in such cases. On the other hand, conviction rates in such cases were lower than when the appellor prosecuted the case to jury trial. Since active participation and even testimony by the appellor is likely in such cases, it is possible that the lower conviction rates reflect the fact the jury lacked sufficient information to convict. ${ }^{41}$ On the other hand, it is also possible that the lower conviction rate reflects the fact that many appellors retracted or failed to prosecute because they knew their cases were weak. The high conviction rate in cases which the appellor settled supports this conjecture. $^{42}$

The evidence in this section has been confined to appeals, which were a small and decreasing proportion of cases. Comparable evidence is impossible to gather in cases prosecuted by presentment, because the records do not indicate whether the victim-accuser appeared at trial. This failure to record, however, is itself probative. If the presence of the victim-accuser were necessary, then it is likely that he or she would have been attached to attend the eyre or at least summoned to do so. In this regard, it is noteworthy that fifteenth-century sheriffs were instructed to summon 'all those who wished to 
prosecute prisoners' at gaol delivery, ${ }^{43}$ but that no comparable summons to prosecutors was issued in the thirteenth century. ${ }^{44}$

\section{Trial accounts}

Trial accounts are potentially the most valuable evidence in establishing whether medieval juries were or were not self informing. McLane, Post and Powell's discussions contain surprisingly few trial accounts, largely because fourteenth- and fifteenth-century sources are so uninformative. Nevertheless, with effort, even sources as arid as gaol delivery plea rolls can be coaxed to yield information on trial procedure, as Musson has demonstrated. ${ }^{45}$ Fortunately, the thirteenth-century sources, which include treatises, plea rolls and early reports, are much more copious. Although each of these sources has its own problems, together they paint a coherent picture. Jurors came to trial already informed. Sometimes they supplemented their knowledge with testimony provided by officials and other witnesses.

\section{Treatises}

The treatise attributed to Bracton, probably written sometime in the late $1220 \mathrm{~s}$ or early 1230s, contains a rather full account of a trial in eyre. I have excerpted the most relevant parts:

We must now speak of those indicted by popular rumour ... When because of rumour and suspicion the truth of the matter ought to be investigated by the country ... the judge, if he is wise, ought first to inquire (if he has doubts and the jury is suspect) from what man or men the twelve jurors have learned what they put forward in their veredictum concerning the indicted man; having heard their answer thereon he may readily decide if any deceit or wickedness lies behind it. For perhaps one or a majority of the jurors will say that they learned the matter put forward in their veredictum from one of their fellow jurors, and he upon interrogation will perhaps say that he learned it from such a one, and so by question and answer the judge may descend from person to person to some low and worthless fellow, one in whom no trust must in any way be reposed. ... [W] hen proceedings of this kind have reached the point of an inquest, in order that judgment may be reached with greater certainty and risks and doubts removed, let the justice inform the indicted man that if he suspects any of the twelve jurors he may remove him for just cause, and let the same be said of the [jurors from] the vills, as where there are deadly enmities between some of them and the indicted man, or there is a greedy desire to get his land, as was said above; if there is ground for suspicion all are to be removed, that inquiry may proceed free of all doubts. When the twelve jurors and the [jurors of] the four townships are present, those of the vills will take an oath first, each by himself or all together; lifting up their hands let them swear in these words: 
'Hear this, ye justices, that we will speak the truth about what is asked of us on the king's behalf, nor will we for any reason fail to tell the truth, so help us God etc.' Then let one of the said justices speak in this way: 'Such a one, who is present, charged with the death of such a one (or some other crime) comes and denies the death and everything else and on this matter puts himself for good and ill upon the words of your mouth. ... And therefore we tell you that on the faith that binds you to God and by the oath that you have taken you are to let us know the truth thereof, nor are you to fail in saying whether or not he is guilty of what is alleged against him ... through fear or love or hate but with God only before your eyes, nor are you to oppress him if he be innocent of the said offence.' His discharge or condemnation will then follow, according to their verdict . . . In all crimes, major and minor, the justices, if they deem it expedient [and] for good reason, [as] where a serious crime is being concealed and the jurors intend to hide the truth through love, hatred or fear, may separate the jurors one from the other and examine each of them individually in order to establish the truth adequately. ${ }^{46}$

This passage is overflowing with evidence that jurors were self informing. If the judge was suspicious of the presenting jurors, he questioned them about the sources of their information. Obviously, the information on which the jurors based their presentment (accusation) was not presented in court; otherwise the judge would not have to ask about it. Once the judge was satisfied with the presentment, the defendant was allowed to challenge the jurors 'for just cause'. Note, however, the examples which Bracton gives for removing a juror: 'deadly enmities' and 'greedy desire to get . . . land'. Knowledge of the facts or parties was not grounds for exclusion. The jurors, including both the presenting jurors and the representatives of the four neighbouring villages, were then sworn and the judge gave them their charge. Then, without any mention of witnesses or evidence, the jurors delivered their verdict and the judge rendered the judgment: 'discharge or condemnation'. Although one can imagine many complex reasons why there is no discussion of witnesses or other evidence, surely the simplest is that witnesses and other evidence were not an ordinary or important part of trial. Finally, Bracton's description of trial ends by noting that if the judge suspected that the jurors were concealing crime, they were to be examined individually. Jurors could only conceal crime, and it only made sense to question them, if they had knowledge beyond what they learned at trial.

The Placita Corone, a treatise most likely composed c. 1274-75, largely confirms Bracton's account. Unlike Bracton, the Placita consists mostly of dialogues of court interactions. Most deal with appeals and show how the parties to such cases should plead. The parties themselves do most of the talking, although occasionally the judge plays a role. ${ }^{47}$ Witnesses are conspicuously absent. In one revealing dialogue, the judge admonishes the defendant, 'Tell the truth, for if you don't we shall get to know it from the country, ${ }^{\text {, }}{ }^{\text {implying }}$ 
that it is 'the country' (i.e. the jury) rather than witnesses who will inform the court of what really happened.

The last part of the Placita is especially enlightening, because it provides four accounts of indictments tried at gaol delivery. ${ }^{49}$ All portray trial as primarily a conversation between the judge and the accused. Unlike the appeal cases, the accuser or victim is completely absent. Instead, the judge takes on a quasi-prosecutorial role, coaxing the defendant into submitting to jury trial or badgering the defendant to confess. Once the defendant submits to jury trial, as in Bracton, there is nothing to report except the verdict. There is no mention of witnesses or other evidence. The following excerpt is typical:

'Sheriff, why has this man been taken?'

'Sir, for the death of a man whom he is supposed to have killed in self defence, as he says.'

'What is your name?'

'Sir, Thomas de N.'

'Thomas, what was the name of the man whom you killed in premeditated attack, feloniously as a felon?'

'Sir, if you please, I have never been a felon and never did mischief to living man, in premeditated attack; and so I have done nothing wrong against the man whose name you ask: who, feloniously as a felon and in premeditated attack tried to kill me on such a day, at such an hour, in such a year in my own house in such a township, for no fault on my part and solely on account of his malice.'

'Tell us the circumstances.'

'Sir, I was unwilling to lend or hire to him a horse for the purpose of riding about his business ... And because I refused him the loan of my horse he ran at me in my own house with a Welsh knife ... I did not at first return his blows; but when I realised that he was set on killing me I started to defend myself: that is to say I wounded him in the right arm with a little pointed knife which I carried, making no further onslaught and acting in this way only to save my own life.'

'Did he die of such wound?'

'In truth sir, I do not know.' $\cdots$

'Thomas, you have greatly embroidered your tale and coloured your defence: for you are telling us only what you think will be to your advantage, and suppressing whatever you think may damage you, and I do not believe you have told the whole truth.'

'Sir, I have told the whole truth, and related the affair from the beginning to the end in every detail: and of this I trust God and the country both for good and evil.'

And so let the inquest be held.

And the jury said the same as Thomas had related. So the justice then says: 
'Thomas, these good people testify by their oaths to the truth of what you have said. So our judgment is that what you did to him, you did in self defence. But we cannot release you from this prison without the king's special grace. However we will send a report of your case to the king's court and ensure that you receive his special grace.'

'Sir, I thank you.'50

Because this is gaol delivery, there is no presenting jury to state the accusation. It is the sheriff, therefore, who takes on this role and thus assumes a speaking part, albeit a small one. The bulk of the case involves a conversation between the judge, who seems quite hostile, and the defendant. The defendant says quite a bit, and in similar real cases, the jurors may have been influenced both by what he said and how he said it. Once the defendant has put himself on the jury, there is again no sign of testimony or evidence. The jury's verdict is reported immediately.

The description of trial in Britton (c. 1290-95) is similar to Bracton's, with two principal differences. Britton allows the defendant to challenge jurors who have served on the presenting jury, and Britton says that if the jurors cannot agree and judicial questioning reveals that the jurors 'know nothing of the fact, let others be called who do know it' ${ }^{51}$ The first difference will be discussed in section IV below. This second difference is very strong evidence that Britton believed that jurors were or should have been self informing. Unfortunately, there is no corroborating evidence for this procedure.

\section{Plea rolls}

Because treatise writers are not completely reliable, it is important to compare their writing to other trial accounts. The most important are probably the eyre rolls, the official Latin record of eyre proceedings. Unfortunately, plea rolls record frustratingly little information. Often they contain only the charge, the jury verdict and miscellaneous amercements. This is especially true of thirteenth-century gaol delivery records which provide only the most skeletal information. Fortunately, for eyre plea rolls, there was wide variation in clerical practice and even a clerk who usually recorded only bare bones facts, occasionally put some life into his writing. Consider, for example, the following case from the 1247 Bedfordshire eyre:

John son of Benedict appealed Ivo Quarel, Osbert Cokel and Henry Wyncard in county court of [breach of the] king's peace, wounds and imprisonment etc. And he [John] now comes and does not want to prosecute them. Therefore let him be committed to jail and his sureties, Ayltrop Balliol and Walter son of Odo, are in mercy [fined]. And Ivo and the others come [to court]. And the jurors testify that they [John, Ivo, Osbert and Henry] have settled and they say that, in truth, the aforesaid Ivo and the others came to the property of Matthew of Leyham in Barford and fished there without Matthew's permission and contrary to his wishes. The aforesaid John came along and asked them for a pledge, and 
the aforesaid Ivo would not give him one, but instead struck the aforesaid John in the head with a hatchet and made two wounds each three inches long down to the crest of the head. And they [Ivo and the others] beat him badly. And afterwards they took him and bound him and put him in a boat and took him from this county [Bedfordshire] to the county of Huntingdonshire to Ivo's house at Buckden. There they dragged him with a rope to a window of Ivo's solarium and forced him to break the window with an axe. And they painted the wall near the window with the blood flowing from the wounds the aforesaid Ivo had given the aforesaid John, and they dragged him through the window and set upon him a blanket and some linen saying that he had stolen them. And they raised the hue [and cry] and caused the men who responded to the hue [and cry] to understand that eighteen thieves had come to his house, and that all except the aforesaid John had gotten away. So they put the blanket and the linen on him and took him to Huntingdon and gave him to the sheriff to be incarcerated. And he remained in prison until his tithing delivered him. Therefore let the aforesaid Ivo and the others be taken into custody. Later Ivo Quarel came and made fine for forty marks ... ${ }^{52}$

What is most notable about this case is the detailed account which the jurors provided of what happened. Although it is possible that they heard testimony in court and then provided this complex narrative as a synthesis of what they heard, this seems implausible. From whom would they have heard such testimony? The appellor, although present at the eyre, did not want to prosecute and had, in fact, settled with the defendants. He is unlikely to have testified. The defendants had no incentive to provide the information. Perhaps third parties, to whom the appellor had previously related his ordeal, testified in court. Most likely, however, the jurors had informed themselves out of court, by talking to the appellor while he was still interested in pursuing the case or by talking to representatives of the relevant villages to whom the appellor might have spoken. They might also have learned from the appellor's presentation of the appeal at the county court. In this regard, it is notable that jurors are said to 'testify' (testantur). They were seen as witnesses themselves. It is unlikely that they were eyewitnesses. Rather, they were hearsay witnesses, synthesising and testifying as to what they heard from others before coming to court.

The jury's testimonial role is highlighted in a case from the 1227 Essex eyre. A chaplain was appealed for arson and claimed benefit of clergy. As was common in such cases, the jurors nevertheless rendered a verdict. They said that he had committed arson and 'they disclosed certain reasons for this' (ostendunt inde certas rationes). ${ }^{53}$ As the theory of the self-informing jury suggests, reasons and facts were not argued to the jury. Rather, jurors offered them to the judge.

While the plea rolls generally support the idea that the jury came to court well-informed of the relevant facts, they also suggest that jurors sometimes 
learned from trial. Not only would trial give the defendant, the judge and the appellor (if it was an appeal) a chance to speak about the case, but other persons are occasionally mentioned in the plea rolls as providing information in open court. A homicide appeal from the 1218 Yorkshire eyre provides a particularly informative example of in-court testimony. After the principal defendant, Simon, was convicted and hanged, the record continues with proceedings against accessories. The key parts are underlined, and the original Latin of important verbs has been supplied:

The same Jordan appeals as accessory Geoffrey of Stallingborough. The sheriff, the neighbourhood, and the jurors bear witness (testantur) that this Geoffrey came before them after Hawisa's death and said that the same Simon had many times asked him to come with him to kill Hawisa, and that on the night on which she was killed he had asked him to go with him and he said that he would not, and immediately Simon went with his daughters and killed her, and if he should wish to deny this he would prove it against him as the court shall adjudge. It was attested (testatum fuit) by the bishop of Durham's serjeant of Howden and the 4 villages and all the neighbourhood that before Geoffrey was taken they found upon him a certain jewel box and border of cloth which they well know (noverunt) to have belonged to Hawisa, and upon William his son they found a razor and tunic which belonged to Peter of Duffield, Hawisa's husband, who has set out to the land of Jerusalem, and William said (dixit) that Geoffrey his father entrusted them to him and Geoffrey denied (dedixit) this.

Afterwards Geoffrey came and admitted (cognovit) that he was present where the aforesaid Hawisa was killed and he appeals thereof William the smith of Duffield ... . ${ }^{4}$

It is apparent that there were a lot of people speaking in court in this case. As would be expected, the appellor, defendant, jurors and representatives of the four villages spoke. The jurors in particular spoke at length, informing the judge of many details about the case. In addition, the sheriff and the neighbourhood (visnetum) joined with the jurors in reporting what Geoffrey had said to them after Hawisa's death. It is unclear exactly how this happened. While the record makes it sound as though the sheriff, the neighbourhood, and jurors spoke in unison, it is far more likely that the sheriff, one or two neighbours, and a representative of the jury spoke one after another, saying roughly the same thing. For similar reasons, the bishop of Durham's serjeant of Howden, neighbours, and representatives of the four nearby villages, probably spoke separately about finding the deceased's goods in the defendant's possession. It is not entirely clear, however, that the serjeant and neighbours spoke in open court, because, unlike the prior testimony, their words are introduced by a past tense verb - testatum fuit rather than testantur. While this change in verb tense might indicate that the testimony was communicated to jurors before the eyre, the eyre rolls are notoriously inconsistent in their use of verb tenses. Later in the same record, Geoffrey's confession is recorded in 
the past tense, even though it clearly happened at the eyre in open court. The record also indicates that William said that his father gave him the razor and tunic which had belonged to the deceased. Again, William probably spoke in court, although the use of the past tense might suggest otherwise.

Because the defendant confessed, there is no verdict in this case. Nevertheless, it suggests that testimony was given in open court and that in appropriate cases such testimony could have provided evidence which influenced jury verdicts. As Maitland noted, there were no rules against in-court testimony. ${ }^{55}$ So many people were summoned to the eyre that it was inevitable that some, especially officials, would have had knowledge about criminal cases. It should not be surprising that those with knowledge wanted to speak at trial, nor that judges allowed them to do so. The fact that witnesses sometimes spoke in court does not necessarily detract from the self-informing nature of the jury. For example, in the case above, the testimony of the serjeant, neighbours, and sheriff seems duplicative. ${ }^{56}$ Everything they said was also said by the presenting jury or four villages, who would have constituted the trial jury if the defendant had not confessed. This case thus provides a nice illustration of how witness testimony at trial is not incompatible with the idea that jurors came to trial already well informed.

Although this case shows that witnesses sometimes testified at trial, it does not prove that they were an ordinary part of criminal trials. To document the frequency and nature of such testimony, I looked for witnesses in four crown pleas eyre rolls. These rolls contain 1300 cases from different parts of England, spanning most of the century. Table 3.2 summarises the frequency of testimony, who the witness was and what he spoke about. The table suggests that testimony was quite uncommon. The plea rolls record only 80 instances of testimony in 1300 cases. That means there was testimony in only 6 per cent of the cases. Even this may exaggerate the extent to which witnesses appeared because the speaker in the overwhelming majority of such instances was not identified. Rather, the testimony is introduced by an ambiguous formula, most often 'Later it was testified that (Postea testatum est quod).' It is possible that such information was actually provided by the jurors, in which case it would not be properly categorised as testimony in the sense used in this chapter. The idea that such formulae were used to introduce words spoken by the jurors is supported by the 1286 Huntingdonshire eyre roll, which often uses the formula 'Later it was testified by the jurors that' (Postea testatum est per juratores quod) rather than 'Later it was testified that' ${ }^{57}$ This suggests that clerks writing other eyre rolls may have used 'Later it was testified that' as a shorthand for 'Later it was testified by the jurors that'. If one counted only cases which explicitly identified the person or group speaking, there were only seventeen instances of testimony. That represents testimony in barely one per cent of cases. Of course, it is possible that there were many instances of testimony which were not recorded, but given the evidence from other sources, such as treatises and reports (discussed below), this seems unlikely. 
Table 3.2 Testimony in eyre plea rolls by topic and speaker, 1221-86

\begin{tabular}{|c|c|c|c|c|c|c|c|}
\hline & Coroner & Sheriff & County $^{\mathrm{h}}$ & $\begin{array}{l}\text { Other } \\
\text { officials }\end{array}$ & Non-officials ${ }^{\mathrm{j}}$ & $\begin{array}{l}\text { Unidentified } \\
\text { speaker }^{\mathrm{k}}\end{array}$ & Total \\
\hline $\begin{array}{l}\text { Law enforcement } \\
\text { misconduct }^{\mathrm{b}}\end{array}$ & 1 & 1 & 2 & 1 & 0 & 20 & 25 \\
\hline Flight $^{\mathrm{c}}$ & 0 & 1 & 0 & 0 & 0 & 13 & 14 \\
\hline Forfeiture $^{\mathrm{d}}$ & 0 & 0 & 0 & 0 & 0 & 14 & 14 \\
\hline Accusation $^{\mathrm{e}}$ & 0 & 0 & 0 & 0 & 0 & 9 & 9 \\
\hline Guilt $^{\mathrm{f}}$ & 1 & 2 & 0 & 1 & 0 & 3 & 7 \\
\hline Other ${ }^{\mathrm{g}}$ & 4 & 0 & 1 & 0 & 2 & 4 & 11 \\
\hline Total & 6 & 4 & 3 & 2 & 2 & 63 & 80 \\
\hline
\end{tabular}

Notes:

a 'Testimony' means words spoken at trial by a speaker not identified as a judge, juror, village, appellor, defendant, attorney of a defendant, or ordinary claiming a defendant as cleric. The table counts instances of testimony. Sometimes, as in the 1218 Yorkshire case quoted above, there was more than one instance of testimony in the same case. As a result, some cases are counted twice or even three times in the table. The eighty instances of testimony occurred in only sixty-eight cases.

b Testimony about individuals, officials, and groups who failed to fulfil their law enforcement responsibilities, including villages that failed to pursue suspects, sureties or bailors who failed to ensure someone's presence at the eyre, and misappropriation of forfeited chattels.

c Testimony about whether a suspect fled or abjured and/or information about suspects who fled or abjured, including whether suspects who fled were tried and/or executed elsewhere.

d Testimony about whether a defendant who fled or was convicted, had chattels or lands and/or their value.

e Testimony which accuses someone not previously mentioned of an offence other than law enforcement misconduct. Such accusations were most often of homicide.

f Testimony about whether a suspect was guilty.

g Testimony which does not fall in any of the above categories, such as that a case was removed to the Bench in Westminster or that a neighbour was sick and thus could not attend the eyre.

${ }^{\mathrm{h}}$ Means that representatives of the county court testified.

'Were the mayor of London and a sheriff's attorney.

' Means an ordinary person, i.e. one not a coroner, sheriff, other official, or representative of the county court.

${ }^{\mathrm{k}}$ Means that the speaker was not identified. For example, the record might simply say 'it was testified that' (testatum est quod). It is possible that the jury was speaking in such instances.

Sources: D. M. Stenton (ed.), Rolls of the Justices in Eyre ... Gloucestershire, Warwickshire and Staffordshire, 1221, 1222 (Selden Society, 59, 1940), pp. 331-415; Meekings (ed.), The 1235 Surrey Eyre, II (32), pp. 379-443; Harding (ed.), Shropshire Eyre, pp. 196-300, 307-9; De Windt and De Windt (eds), Royal Justice, pp. 292-408, 476-87.

The topics of the testimony are also revealing. The overwhelming majority of the testimony was about collateral matters rather than a defendant's guilt or innocence. For example, almost a third of the testimony was about law enforcement misconduct, such as a village's failure to pursue a fleeing suspect or a pledge's failure to produce someone at the eyre. Much of the remaining testimony concerned whether a suspect had fled or abjured and/or whether such a suspect was tried and/or executed elsewhere. In addition, a substantial amount of testimony was about forfeited chattels or lands. Only sixteen instances of testimony were about matters at the core of the jury's function: 
accusations of felony and the guilt or innocence of the accused. This means that testimony like that in the Yorkshire 1218 case quoted above is recorded to have occurred in barely one per cent of cases. The fact that testimony was almost always about collateral matters may help explain why it is not mentioned in other sources, such as treatises or Year Book reports.

It is also worthwhile to note the positions of those identified as speakers. The most common were officials, such as the sheriff and coroner. Since such persons were heavily involved in the law enforcement activities prior to the eyre, and since they were required to be at the eyre, it is not surprising that they often had useful information to contribute. It was extremely rare for ordinary persons to be recorded as speaking at trial. I found only two such instances in the 1300 cases examined.

One important, unresolved, issue about this testimony is whether it was sworn. Maitland thought it was not ${ }^{58}$ and this view is supported by the lack of any mention of witness oaths in the plea rolls or treatises. Although arguments from silence are always dangerous, given the copious evidence for oaths by jurors, appellors, appellees (defendants in appeals) and compurgators, silence here is quite telling. On the other hand, the plea rolls often make use of the verb 'to testify' (testari), which might suggest that witnesses were sworn.

The plea roll evidence thus substantially augments our knowledge by showing that there was occasional in-court testimony. Nevertheless, such testimony seems to have been rare and largely restricted to collateral matters. In addition, it was probably provided most often by officials rather than by ordinary persons.

\section{Year Book reports}

The last few pages have focused on plea rolls, the official record of court proceedings. Toward the end of the thirteenth century, a new form of legal literature emerged - reports, often called Year Books. These were unofficial notes on cases, probably written down by lawyers for themselves and each other. The overwhelming majority of these reports deal with civil cases, but, as Seipp has noted, there was a trickle dealing with criminal cases. ${ }^{59}$ Some of the reports provide vivid insights into the conduct of trials, because, like the Placita Corone, they take a dialogue form which seems to record what actually transpired in court. Unlike the Placita, however, the reports are about actual cases, not hypotheticals. The following case from the 1293-94 Yorkshire eyre is illustrative of the richness of some reports:

Judge: Hugh, it was presented to us that you committed rape ... how do you want to acquit yourself?

Hugh: Lord, I request that I be able to have counsel lest I be deceived in royal court for lack of counsel.

Judge: You ought to know that the king is a party to this case and prosecutes you ex officio, and in this situation the law does not allow you to have counsel 
against the king... And therefore, on the king's behalf, we order all the pleaders who are your counsel to withdraw.

[The pleaders were removed.]

...

Judge: Do you consent to these twelve honest men, because we know that they do not want to lie for us? ...

Hugh: I consent to my peers, but not to the twelve who accused me ...

[Hugh successfully challenged several of the jurors.]

Judge: We accuse Lord Hugh of the rape of this woman. He denied it. Asked how he wants to acquit himself, he said 'by good country' and put himself on you for good or bad. And therefore we order you, by virtue of your oath, to tell us whether Lord Hugh raped this woman or not.

The twelve: We say that she was raped with force by Hugh's men.

Judge: Did Hugh consent to the deed or not?

The twelve: No.

Judge: Did they know her carnally?

The twelve: Yes.

Judge: Against the woman's will or with her consent?

The twelve: With her consent...

Judge: Lord Hugh, because they acquit you, we acquit you. ${ }^{60}$

Like the accounts in the Placita Corone, trial was primarily a dialogue between the judge and the defendant. The judge took a quasi-prosecutorial role, expelling the defendant's lawyers, and, in passages omitted above, challenging his claim to clerical privilege and bullying him into submitting to jury trial. As in Britton, the defendant was allowed to challenge jurors who had served on the presenting jury. Once the jury selection process was over, the judge immediately charged the jury. As in all of the treatises and most of the plea roll accounts, there is no mention of witnesses. Given the lavish detail with which other aspects of this case were recorded, it would be surprising for the reporter to have omitted witness testimony and arguments about such testimony, if witnesses had in fact testified. The latter part of the report is a dialogue between the judge, who seems to have known nothing of the facts, and the jurors, who tell him what they knew (or, perhaps, what they wanted him to believe). The independence of jurors from what was said in court is underlined by the fact that, while the presentment and preliminary proceedings had said nothing about accomplices, the jurors' verdict states that it was Hugh's men, not Hugh himself, who had intercourse with the woman.

On the whole, this and other thirteenth-century reports confirm the accounts given in the treatises. ${ }^{61}$ The testimony of witnesses is never mentioned. Rather, trial was primarily a conversation between the judge and the defendant, and secondarily between the judge and the jury. Immediately after being impanelled, or perhaps after some deliberation, ${ }^{62}$ the jury rendered its verdict. 


\section{Explaining the decline of the self-informing jury}

This chapter has tried to show that thirteenth-century jurors were self informing. By the mid-fifteenth century, however, it is clear that jurors were becoming increasingly dependent on in-court testimony. Why did the jury become less self informing? Undoubtedly, increased mobility and other social changes played a large role. ${ }^{63}$ The essays by McLane and Post, however, suggest that fourteenth-century changes in jury composition played a part, at least in criminal cases. This timing suggests two explanations: the transition from eyre to gaol delivery ${ }^{64}$ and the exclusion of presenting jurors from the trial jury.

The last regular eyre was held in the early 1290s. By that time, and probably several decades earlier, gaol delivery had become the principal forum in which criminal cases were heard. The rise of gaol delivery undoubtedly represented an improvement in the justice system. Eyres were held infrequently - every four years at the turn of the thirteenth century and with decreasing frequency thereafter. Decades might separate eyres toward the end of the century. Even four years was a long time to hold a homicide suspect in gaol before trial, to expect jurors to remember the facts, or to require appellors to remember the exact phrasing of their pleadings in county court. Gaol delivery sessions, which were held roughly twice a year, dramatically alleviated the problems caused by delay. Such frequent sessions, however, had at least one unanticipated effect: they made it difficult to recruit local jurors.

For eyres, recruitment of jurors was relatively easy. Although the sheriff summoned all freeholders, this was not a heavy burden, because the eyre met so infrequently. In addition, because the eyre was the forum for a wide variety of civil and criminal cases, many individuals had to attend anyway. Finally, those who served on juries would have perceived the importance of their presence, because jurors from all but the smallest hundreds would have been involved in more than a dozen cases. Even the representatives of the villages, who were specially summoned, would probably have been involved in at least a few cases.

Recruitment for gaol delivery was very different. Such sessions were held much more frequently, so summoning all freeholders and representatives from every village to each session, would have imposed a huge burden. In fact, doing so was forbidden by statute. ${ }^{65}$ Even though gaol delivery sessions were often held at the same time as assizes for civil cases, because assize sessions were also held more frequently, fewer people had litigation to attend to. In addition, the increasing employment of attorneys and pleaders meant the parties themselves might not attend even if they had pending cases. As a result, jurors had to be specially summoned and naturally found service burdensome. In addition, because gaol delivery sessions were held so frequently, relatively few cases were heard at any one session. As a result, jurors would have felt that service was not worth the effort. If hundred jurors appeared, 
they likely would have had only one or two cases to try. If representatives of the village appeared, they would likely have tried only a single case. Not surprisingly, although representatives of the villages were still summoned, sheriffs seem to have given up trying to get them to attend. The plague must have aggravated these problems by drastically reducing the population - thus reducing both the pool of potential jurors and the number of suspects tried - without reducing the number of hundreds.

Not surprisingly, coroners, bailiffs, assize recognitors, and others with independent reasons to attend gaol delivery came to constitute a disproportionate fraction of jurors. ${ }^{66}$ There were not enough of these, however, to fully staff juries of all the relevant hundreds, so judges and sheriffs had to improvise. Pugh, Post, and Powell documented the strategies they employed. Given the dynamics of juror recruitment at gaol delivery, one should not be surprised at the difficulty of assembling jurors with local knowledge. If anything, it is surprising that sheriffs were able to recruit juries that were largely hundredbased for so long. One might have thought that the system described by Powell - juries composed of men from several hundreds trying suspects from multiple hundreds - would have appeared a century earlier.

The problem created by the frequency of gaol delivery sessions was compounded by the exclusion of presenting jurors from the trial jury. As Britton and the Year Book report quoted above show, defendants in the late thirteenth century had the right to challenge jurors who had indicted them. In 1352, this protection was enacted into statute. ${ }^{67}$ Although the purpose of this change was clear (to ensure a fair trial), it, like the introduction of gaol delivery, had an unintended effect: barring twelve of the most knowledgeable people, the presenting jury, from service on the trial jury.

These developments suggest that as the Middle Ages drew to a close, juries contained fewer informed members. They do not prove, however, that the late medieval jury was no longer self informing or that it relied principally on evidence presented in court by parties or witnesses. Powell pointed out that jurors from the hundred were partly replaced by officials, such as coroners, hundred bailiffs and constables. Because of their involvement in pre-trial processes, these jurors came to court with significant information about suspects. ${ }^{68}$ In addition, fourteenth-century gaol delivery juries still consisted overwhelmingly of men from the hundred and fifteenth-century juries usually contained several from the relevant hundred. It is hard to imagine that these jurors would not have heard the local view on guilt or innocence. ${ }^{69}$ Perhaps they were already acquainted with the suspect and the alleged crime from gossip or from discussions at local courts where the suspect may have been presented or indicted. In addition, jurors from the hundred could have discussed the case with neighbours, officials and others with relevant information about the crime and the suspect's character. Since relatively few suspects from a given hundred were tried at a gaol delivery, a juror's fact-finding burden would not have been large. In fact, a conscientious juror, cognisant that his verdict 
would have life or death consequences, would have been highly motivated to acquire relevant information. He could then have shared it with fellow jurors who, because they resided farther from the relevant events, could not gather evidence on their own. As noted earlier, self informing is a matter of degree. A jury with only one or a few informed jurors is less self informing than one composed exclusively of those from the immediate vicinity of the crime. It may, nevertheless, be self-informing in the sense that jury verdicts could have been based primarily on what at least one juror knew before coming to court rather than on evidence presented by parties or witnesses.

On the other hand, when juries come to contain so few members with independent information, it is easy to see how pressure would build for more in-court presentation of evidence. Jurors might be reluctant to convict based solely on the word of one of their fellows. They might want to hear themselves from those with first-hand knowledge. In addition, an accuser or witness who was unable to persuade a neighbour juror, might travel to gaol delivery himself to try to sway those who came from farther away. In this way, as jurors came less and less frequently from the hundred, prosecutors and witnesses might have come to play a larger role, and self-informed jurors a smaller one.

\section{Conclusion}

This chapter has tried to suggest and support a moderate position: the thirteenth-century jury was self informing, but it sometimes heard witnesses at trial. As Green put it, the self-informing jury was not 'a mythical beast'. ${ }^{70}$ Jurors were recruited from both the hundred and the neighbouring villages and thus knew an enormous amount about cases before they came to court. Sometimes they also heard testimony, but such testimony was usually unnecessary. It was frequently testimony by officials and almost always about collateral matters. As a result, what distinguishes the medieval from the modern jury is not that one heard witnesses and the other did not. Rather, it is that medieval jurors came to court with extensive knowledge about the case and the defendant. They heard testimony, but they heard much less, and what they heard was less important.

\section{Notes}

1 The author thanks Albert Alschuler, Jennifer Arlen, Paul Brand, Jamaul Cannon, David Cook, Charles Donahue, George Fisher, Christina Foster, Thomas Gallanis, Thomas Green, Ariela Gross, Richard Helmholz, Eugene Kantorovich, John Langbein, Edward McCaffery, Anthony Musson, Jennifer Murray, Christopher Stone, and David Seipp for their help, suggestions, and criticism at various stages of this project. This research was supported by a Fulbright scholarship, the National Science Foundation (Law and Social Science Program, grant no. SBR9412044), the Social Science Research Council, and USC Law School summer research grants. 
2 F. Palgrave, The Rise and Progress of the English Commonwealth (2 vols, London, 1832), I, pp. 243-4; H. Brunner, Die Entstehung der Schwergerichte (Berlin, 1872), pp. 427, 452; J. F. Stephen, A History of the Criminal Law of England (3 vols, London, 1883), I, pp. 255-65; F. Pollock and F. W. Maitland, The History of English Law before the Time of Edward I (second edition, 2 vols, Cambridge, 1988), II, pp. 622-8; J. P. Dawson, A History of Lay Judges (Cambridge, Massachusetts, 1960), pp. 213-27; S. F. C. Milsom, Historical Foundations of the Common Law (second edition, Toronto, 1981), pp. 412, 418, 421, 424; J. H. Baker, Introduction to English Legal History (third edition, London, 1990), pp. 88-90. See also, below, notes 3-6. For historians who disagree with this consensus, see below, notes 7, 10 and 13.

3 J. H. Langbein, 'The origins of public prosecution at common law', American Journal of Legal History, 17 (1973), 314.

4 J. B. Thayer, A Preliminary Treatise on Evidence at the Common Law (Boston, 1898), 85-136; J. H. Wigmore, A Treatise on the Anglo-American System of Evidence (third edition, 10 vols, Boston, 1940), I, p. 235; V, pp. 10-12. More recent research suggests that rules regulating oral testimony did not develop until the eighteenth century, and thus that the decline of the self-informing jury was a necessary condition but not the immediate cause of the emergence of evidence law. See J. H. Langbein, 'Historical foundations of the law of evidence: a view from the Ryder sources', Columbia Law Review, 96 (1996), 1171-2; T. P. Gallanis, 'The rise of modern evidence law', Iowa Law Review, 84 (1999), 499, 537-40.

5 Langbein, 'Origins', 314; J. H. Langbein, Prosecuting Crime in the Renaissance (Cambridge, Massachusetts, 1974), pp. 22, 43, 118-22, 204-5.

6 T. A. Green, Verdict According to Conscience: Perspectives on the English Criminal Trial Jury 1200-1800 (Chicago, 1983), pp. 16-18.

7 M. C. Klingelsmith, 'New readings of old law', University of Pennsylvania Law Review, 66 (1918), 107-22; R. C. Palmer, 'Conscience and the law: the English criminal jury', Michigan Law Review, 84 (1986), 795-6.

8 J. S. Cockburn and T. A. Green (eds), Twelve Good Men and True: The Criminal Trial Jury in England, 1200-1800 (Princeton, New Jersey, 1988).

9 The hundred was an administrative subdivision of the county comprising a number of villages.

$10 \mathrm{~J}$. B. Post, 'Jury lists and juries in the late fourteenth century', in Cockburn and Green (eds), Twelve Good Men, p. 76; E. Powell, 'Jury trial at gaol delivery in the late Middle Ages: the Midland Circuit, 1400-1429', ibid., p. 113.

11 Powell, 'Jury trial', p. 97 ('Our hypothesis must be that by the early fifteenth century the criminal trial jury was no longer self informing in the accepted sense - if indeed it ever had been') (italics added).

12 Ibid., pp. 115-16.

13 G. Fisher, 'The jury's rise as lie detector', Yale Law Journal, 107 (1997), 591-2.

14 T. A. Green, 'A retrospective on the criminal trial jury, 1200-1800', in Cockburn and Green (eds), Twelve Good Men, pp. 364-75; Langbein, 'Historical Foundations', 1170 n. 6; see also B. W. McLane, 'Juror attitudes toward local disorder: the evidence of the 1328 Lincolnshire trailbaston proceedings', in Cockburn and Green (eds), Twelve Good Men, p. 57.

15 A. Musson, Public Order and Law Enforcement: The Local Administration of Criminal Justice, 1294-1350 (Woodbridge, 1996), p. 205. 
16 See, e.g., Langbein, 'Origins', 314; Green, Verdict, pp. 16-17; see also twentiethcentury sources cited in note 2.

17 Fisher, 'Jury's rise,' 593.

18 Women constituted more than a third of appellors. D. Klerman, 'Women prosecutors in thirteenth-century England', forthcoming in Yale Journal of Law and Humanities.

19 Powell, 'Jury trial', pp. 115-16 (italics added).

20 J. H. Mitnick, 'From neighbor-witness to judge of proofs: the transformation of the English civil juror', American Journal of Legal History, 32 (1988), 201-35.

21 Green, 'Retrospective', p. 370.

22 Powell, 'Jury trial', pp. 97, 115-16.

23 Green, Verdict, p. 16 ('No witnesses could come forward ...'); Langbein, 'Historical foundations', 1170 ('The medieval jury came to court not to listen but to speak, not to hear evidence but to deliver a verdict formulated in advance.'); but see Green, Verdict, p. 16 n. 48, p. 18; Langbein, 'Origins', 314, quoted above, p. 58 ('more to speak than to listen' rather than 'not to listen') (italics added).

24 Green, Verdict, p. 18.

25 F. W. Maitland, Pleas of the Crown for the County of Gloucester . . 1221 (London, 1884), p. xli; Stephen, History, pp. 259-60.

26 'Jurors, evidences, and the tempest of 1499', in J. W. Cairns (ed.), The Dearest Birthright of the People of England (forthcoming).

27 The presenting jury was a jury which accused persons of crime. It was the forerunner of the grand jury.

28 The eyre was a periodic session of royal justice held in the countryside to hear a wide range of civil and criminal cases.

29 C. A. F. Meekings (ed.), The 1235 Surrey Eyre, 2 vols, Surrey Record Society, 31 , 32, 1979-83, I (31), pp. 20, 94, 97-8. Even though the representatives of the villages were sworn and associated with the presenting jurors in presenting the verdict, the sources do not always refer to them as 'jurors.' For example, plea rolls often report the verdict in a form that suggests that the villagers were not part of the jury: 'The jurors and the four neighbouring villages say on oath that ...' See, e.g., A. Harding (ed.), The Roll of the Shropshire Eyre of 1256, Selden Society, 96, 1981 , p. 230. See also below p. 73, where the jury is referred to as 'the twelve'. Nevertheless, because the villagers were sworn and seem to have delivered their verdict with the presenting jurors, this chapter will refer to them as part of the jury, as is common in the literature.

30 See e.g., Harding (ed.), Shropshire Eyre, pp. 301-6; A. R. and E. B. DeWindt (eds), Royal Justice and the Medieval English Countryside: The Huntingdonshire Eyre of 1286, the Ramsey Abbey Banlieu Court of 1287, and the Assizes of 1287-88 (Toronto, 1981), pp. 419-21.

31 Meekings (ed.), 1235 Surrey Eyre, I, p. 97.

32 An amercement was a monetary penalty. Today it would be called a fine.

33 See e.g. Harding (ed.), Shropshire Eyre, cases 514, 535, 544, 565.

34 Gaol delivery was a periodic session of royal justice in the countryside specifically to try those in jail or out on bail.

35 Pollock and Maitland, History, II, p. 625.

36 R. B. Pugh, Wiltshire Gaol Delivery and Trailbaston Trials, 1275-1306, Wiltshire Record Society, 33, 1978, pp. 18-19. 
37 JUST 1/36, mm. 4-5 (Berkshire 1225 gaol delivery, seventeen cases mentioning the neighbouring vills); JUST 1/1177A, m. 4d (Suffolk 1250 gaol delivery, three cases mentioning neighbouring vills); JUST 1/1179, m. 14 (Suffolk 1254, three cases mentioning neighbouring vills); JUST 1/1179, mm. 25-25d (Norfolk and Suffolk gaol delivery 1259, thirteen cases mentioning neighbouring vills); JUST 3/18/2, m.1 (Essex 1282 gaol delivery, eight cases mentioning the neighbouring vills).

38 See above, note 10; J. G. Bellamy, The Criminal Trial in Later Medieval England (Toronto, 1998), pp. 103-4.

39 D. Klerman, 'Settlement and the decline of private prosecution in thirteenthcentury England', Law and History Review, 19 (2001), 38-40, 50-3. This article did not address the treatment of appeals when the appellor died, but the same pattern appears in those cases as well.

40 Ibid., 21-2.

41 No inferences should be drawn from the fact that jurors were less likely to convict when the appellor had died than when the appellor had retracted or decided not to prosecute, because the difference in conviction rates is not statistically significant.

42 For an example of such a case, see below, pp. 67-8. For a discussion of the high conviction rates in such cases, see D. Klerman, 'The selection of thirteenthcentury criminal cases for trial' (unpublished manuscript).

43 Powell, 'Jury trial', p. 107; Bellamy, Criminal Trial, p. 103. Note, however, that Bellamy believes the purpose of this proclamation was primarily to inform appellors, not victims prosecuting their cases by indictment.

44 Meekings (ed.), 1235 Surrey Eyre, I, p. 20; Close Rolls of the Reign of Henry III, $A D$ 1227-1231 (London, 1902), pp. 227, 228, 386, 388-9 (1229 and 1230 gaol deliveries); JUST 3/14/1, m. 11 (Devon 1271 gaol delivery).

45 Musson, Public Order, pp. 201-5.

46 S. E. Thorne (trans.), Bracton on the Laws and Customs of England (4 vols, Cambridge, Massachusetts, 1968-1977), II, pp. 403-6, fols 143-143b. Square brackets, parentheses and the items within them are Thorne's.

47 J. M. Kaye (ed.), Placita Corone or La Corone pledee devant justices, Selden Society, Supplementary Series, 4, 1966, pp. 8-9, 16-17.

48 Ibid., p. 8.

49 Ibid., pp. 17-22.

50 Ibid., pp. 19-20.

51 F. M. Morgan (ed.), Britton (Oxford, 1865), pp. 30, 31.

52 JUST $1 / 4$, m. 30.

53 JUST $1 / 229$, m. 16.

54 D. M. Stenton (ed.), Rolls of the Justices in Eyre Being Rolls of Pleas and Assizes for Yorkshire in 3 Henry III (1218-19), Selden Society, 56, 1937, pp. 299-301.

55 Pollock and Maitland, History, II, p. 628.

56 For another example of duplicative testimony, see J. G. Jenkins, Calendar of the Roll of the Justices on Eyre, 1227, Buckinghamshire Archaeological Society, 6, 1945 , case 527.

57 De Windt and DeWindt (eds), Royal Justice, cases 348, 351, 352, 363, 384, 392, 528, 571, 656; but see cases 363, 388, 442 .

58 Pollock and Maitland, History, II, p. 628. 
59 D. Seipp, 'Crime in the Year Books', in C. Stubbing (ed.), Law Reporting in Britain (London, 1995), pp. 16-17. Seipp was kind enough to share with me his list of late thirteenth-century Year Book cases involving crime.

60 YB 30-31 Edward I, pp. 529-32. Contrary to the Year Book editor's suggestion, this case is from the Yorkshire eyre. D. Crook, 'Triers and the origin of the grand jury', Journal of Legal History, 12 (1991), 116 n. 71.

61 YB 30-31 Edward I, pp. 521, 528-9, 534, 535, 538-9, 541.

62 Ibid., p. 541; Britton, p. 31.

63 Langbein, 'Origins', 315.

64 D. Crook, 'The later eyres', English Historical Review, 97 (1982), 241, 246-7.

65 Provisions of Westminster, 1259 (43 Henry III Provisions), c. 13; Statute of Marlborough, 1267 (52 Henry III Stat. Marlb.), c. 18.

66 Powell, 'Jury trial', pp. 88-94.

6725 Edward III, stat. 5, c. 3.

68 Powell, 'Jury trial', pp. 88-94.

69 Green, 'Retrospective', pp. 369.

70 Ibid., p. 370. 